Svein Ulstad

Nord universitet

Vegard Rønning Valstadsve

Nord universitet

Knut Skjesol

Nord universitet

DOI: http://dx.doi.org/10.5617/adno.7826

\title{
Mestringsorientert klima - veien til høy innsats, indre motivasjon og karakter i kroppsøving
}

\begin{abstract}
Sammendrag
Denne studien er basert på målorienteringsteorien (Achievement Goal Theory - AGT) og selvbestemmelsesteorien (Self-Determination Theory - SDT) som en teoretisk ramme. Hensikten med studien er å se på sammenhengen mellom oppfattet motivasjonsklima og de tre grunnleggende psykologiske behovene for autonomi, kompetanse og sosiale relasjoner i kroppsøving. Videre vil vi se på sammenhengen mellom, tilfredsstillelse eller frustrasjon av behovene og innsats, indre motivasjon og karakter. Undersøkelsen er gjennomført som en spørreundersøkelse på fire videregående skoler i Trøndelag med 231 respondenter. Structural Equation Modeling (SEM) ble brukt til å analysere dataene. Resultatene viser at et mestringsorientert klima hadde en positiv sammenheng med tilfredsstillelse av de tre grunnleggende behovene, og at et prestasjonsorientert klima hadde en positiv sammenheng med frustrasjon av de tre grunnleggende behovene. Resultatene viser også at tilfredsstillelse av de tre grunnleggende behovene hadde en positiv sammenheng med innsats, indre motivasjon og karakterer, mens frustrasjon av behovene hadde en negativ sammenheng med innsats. Analyser viser at et mestringsorientert klima har en indirekte positiv sammenheng med indre motivasjon, innsats og karakterer via tilfredsstillelse av behovene, og at et prestasjonsorientert klima har en indirekte negativ sammenheng med innsats via frustrasjon av behov, og en negativ sammenheng med indre motivasjon via dekking av behov. A sette mestring og utvikling foran prestasjoner og sosial sammenligning trekkes fram som et viktig element i lærerarbeidet. Det er også viktig å legge til rette for gode relasjoner, at elevene får valgmuligheter i undervisningen og at aktiviteter gir mulighet for mestring. Denne studien tar for seg forskning som forhåpentligvis vil bidra til økt bevissthet rundt motivasjonsklima, grunnleggende behov og innsats, indre motivasjon og karakterer på videregående skoler.
\end{abstract}

Nøkkelord: målorienteringsteorien, selvbestemmelsesteorien, innsats, indre motivasjon, kroppsøving 


\title{
A mastery-oriented climate - the way to high effort, intrinsic motivation and performance in physical education
}

\begin{abstract}
This study is based on the Achievement Goal Theory (AGT) and Self-Determination Theory (SDT) as a theoretical framework. The purpose of the study is to look at the relationship between perceived motivational climate and the three basic psychological needs for autonomy, competence and social relationships in PE. Furthermore, we will look at the relationship between, satisfaction or frustration of the needs, and key learning indicators (effort, inner motivation and grade). The survey has been conducted at four high schools in Trøndelag with 231 respondents. SEM analyses were performed in Mplus. The results show that a mastering climate had a positive connection to satisfaction of the three basic needs, and that a performance-oriented climate had a positive connection to the frustration of the three basic needs. The results also show that satisfaction of the three basic needs had a positive connection to intrinsic motivation and grades, while the frustration of the needs had a negative relation to effort. Further, we have indirect effect from mastery climate to effort, intrinsic motivation and performance through need satisfaction, and an indirect effect from performance climate to effort through both need frustration and need satisfaction. Highlighting mastery and development instead of achievement and social comparison is emphasized as an important element in the teaching work. It is also important to facilitate good relationships, and that activities provide the opportunity for coping. This research will hopefully contribute to increased awareness of the motivation climate, basic needs and learning indicators of upper secondary schools in Norway.
\end{abstract}

Keywords: achievement goal theory, Self-determination theory, effort, intrinsic motivation, physical education.

\section{Innledning}

Kroppsøvingsfagets formål er å inspirere til fysisk aktivitet og livslang bevegelsesglede (Utdanningsdirektoratet, 2015). Elever forholder seg ulikt til fysisk aktivitet og forutsetningene er forskjellig knyttet til både kompetanse, ferdigheter og motivasjon (Skaalvik \& Skaalvik, 2015). Elevene kan ha ulike oppfatninger av hvordan faget formidles av læreren (Säfvenbom, Haugen \& Bulie, 2014). Hvorvidt elevene føler at de får utfordringer og lærer nye ferdigheter i kroppsøving kan være viktig for elevenes interesse og motivasjon (Cox \& Williams, 2008). Bevegelsesgleden og aktivitetsnivået i faget kan øke hvis aktivitetene styres basert på elevenes valg og interesser, og at de føler seg som en del av aktivitetene (Standage, Duda \& Ntoumanis, 2005; Sun \& Chen, 2010). Helsegevinsten med å være fysisk aktiv i hverdagen er stor og anbefalingene for barn og unge i skolen er 60 minutter fysisk aktivitet hver dag (Helsedirektoratet, 2016). Antall timer kroppsøving i uka vil ikke tilfredsstille disse anbefalingene, men faget vil være en bidragsyter og kan stimulere til mer fysisk aktivitet blant barn og unge. Dette er en av flere grunner til fagets viktige rolle i skolen. Det er 
en stor og vanskelig pedagogisk oppgave å tilrettelegge for at alle elevene finner kroppsøving interessant og meningsfullt. Med målorienteringsteorien (Achievement Goal Theory - AGT (Nicholls, 1984)) og selvbestemmelsesteorien (Self-Determination Theory - SDT (Deci \& Ryan, 2000)) som en teoretisk ramme for undersøkelsen, vil vi se på relevante faktorer som kan ha påvirkning på elevenes læring. Utfallsvariabler som er valgt i denne oppgaven er innsats (Utdanningsdirektoratet, 2012), indre motivasjon (Ryan \& Deci, 2007; Ryan \& Deci, 2000) og karakter. Hensikten med denne undersøkelsen er å bidra med økt kunnskap og gjøre kroppsøvingslærere i videregående skole mer bevisste på deres arbeid for å legge til rette for å fremme innsats og indre motivasjon. I denne artikkelen vil fokuset være å se på sammenhengen mellom elevenes oppfattelse av det motivasjonelle klimaet i kroppsøvingsklassen, elevenes grunnleggende behov, innsats, indre motivasjon og karakter.

\section{Teori}

\section{Motivasjonelt klima}

Det motivasjonelle klima vil ha mye å si for elevenes motivasjon, innsats og selvoppfattet kompetanse (Ames, 1992a; Cecchini et al., 2001; Cox \& Williams, 2008; Ferrer-Caja \& Weiss, 2000; Reinboth \& Duda, 2006). Det motivasjonelle klimaet kan deles inn i mestringsorientert klima og prestasjonsorientert klima (Ames, 1992b, 1992c; Biddle, 2001; Roberts, 2001).

I et mestringsorientert klima vil god innsats og individuell framgang roses, og alle hjelper hverandre for å utvikle seg (Cecchini et al., 2001; Cox, 2007). I et slikt miljø er det fokus på at alle skal få likeverdig anerkjennelse og oppmerksomhet, uavhengig av ferdigheter og prestasjoner. Det er aksept for at elevene prøver og feiler i læringsarbeidet, og elevene vil også få valg og innflytelse i undervisningen (Epstein, 1988; Epstein, 1989; Ommundsen, 2006). Når prøving og feiling er en naturlig del av læringen, er det grunn til å tro at et slikt klima virker mindre psykologisk truende på elevene. I et mestringsorientert klima føler ikke elevene en usikkerhet ovenfor egne ferdigheter, og søken etter utfordrende oppgaver og aktiviteter kan dermed bli større (Ommundsen, 2006).

I et prestasjonsorientert klima vektlegger læreren betydningen av konkurranse og sosial sammenligning mellom elevene, der ros og anerkjennelse blir gitt ulikt og er basert på ferdigheter (Ames, 1992a). Det å vinne betyr mest, og lærerne er opptatt av konkurranse i klassen der valg og medbestemmelse for elevene er nærmest utelukket (Ommundsen, 2006). I et prestasjonsorientert miljø vil dårlige prestasjoner bli straffet, og det er liten aksept for prøving og feiling, da dette sees på som fravær av ferdigheter (Cecchini et al., 2001; Cox, 2007; Ommundsen, 2006). 


\section{De tre grunnleggende psykologiske behovene}

Autonomi, kompetanse og tilhørighet er de tre grunnleggende psykologiske behovene SDT har som et grunnlag for motivasjon (Deci \& Ryan, 2002). SDT hevder at tilfredsstillelse av disse behovene er nødvendig for menneskers trivsel, vekst og psykisk utvikling (Deci \& Ryan, 2002). Ifølge SDT vil indre motivasjon forekomme i større grad hvis individet får tilfredsstilt disse tre grunnleggende psykologiske behovene (Deci \& Ryan, 2000).

Elevenes trivsel, indre motivasjon og god helse henger sterkt sammen med tilfredsstillelse av autonomi, kompetanse og tilhørighet (Vansteenkiste \& Ryan, 2013; Chen et al., 2015). Tilfredsstillelse av behovene vil også føre til en bedre selvfølelse for elever i skolen (Cheon, Reeve, Yu \& Jang, 2014; Vansteenkiste \& Ryan, 2013). Det er en direkte positiv link mellom tilfredsstillelse av behovene og en bedre selvfølelse og livskvalitet (Chen et al., 2015). Dette er viktig med tanke på kroppsøvingsfagets formål om et positivt selvbilde og livslang bevegelsesglede.

Lav tilfredsstillelse av behovene resulterer i lav trivsel (Cordeiro, Paixão, Lens, Lacante \& Luyckx, 2016). Frustrasjon av behovene kan skape passivitet, mistrivsel og psykiske problemer som depresjon og utbrenthet (Bartholomew, Ntoumanis, Ryan, Bosch \& Thøgersen-Ntoumani, 2011; Chen et al., 2015). Per definisjon involverer frustrasjon av behovene lav tilfredsstillelse, men lav tilfredsstillelse betyr ikke nødvendigvis at det er frustrasjon til stede (Cordeiro et al., 2016; Vansteenkiste \& Ryan, 2013). Frustrasjon av behovene vil gå rett inn i individet og være ødeleggende.

Tilfredsstillelse eller frustrasjon av de grunnleggende behovene hos elevene avhenger av klimaet og sosiale interaksjoner. Alle faktorer som påvirker variasjonen av tilfredsstillelse eller frustrasjon av behovene, vil også påvirke variasjoner i trivsel og motivasjon (Ryan \& Deci, 2017). Tilfredsstillelse av de tre behovene kan variere fra elev til elev, men en balansert og høy tilfredsstillelse av alle tre relateres i sterkest grad til trivsel (Ryan \& Deci, 2017).

Behovet for autonomi refererer til ønsket om og opplevelsen av frihet, basert på egne verdier, mål og interesser (Deci \& Ryan, 2000). Behovet handler om hvorvidt individet føler seg selv som kilden til atferden (Sun \& Chen, 2010). Ved tilfredsstillelse av behovet for autonomi, kan individet oppleve at kilden til atferd er skapt av egen vilje og ønske (Chen et al., 2015). Frustrasjon av behovet for autonomi innebærer en følelse av å bli kontrollert av indre eller ytre press. Sett i sammenheng med kroppsøving, vil det innebære at elevene føler at aktivitetene er noe som de må gjøre, og at det er noe de trolig ikke ville valgt selv (Chen et al., 2015). Tilfredsstillelse av autonomi har en sterk sammenheng med et mestringsorientert klima (Bartholomew et al., 2011; Cox \& Williams, 2008; Hein \& Caune, 2014).

Behovet for kompetanse handler om menneskets indre behov for å oppnå og utvikle kunnskap, og egne oppfatninger av kompetanse (Strandkleiv, 2006). Jo mer eleven føler seg kompetent, desto mer indre motivasjon skapes (Sun \& Chen, 
2010). Dette innebærer en følelse av at en kan oppnå ønsket utfall basert på egne målsetninger eller mål og krav satt av læreren (Chen et al., 2015; Deci \& Ryan, 2002). Frustrasjon omkring kompetanse knyttet til kroppsøving handler om en følelse av at en mislykkes og har store tvil om egen kompetanse. Frustrasjon av dette behovet kan være et utgangspunkt for dårlig selvoppfattet kompetanse, noe som kan resultere i fravær av motivasjon (Ntoumanis, 2001). Tilfredsstillelse eller frustrasjon av behovet for kompetanse kan også ha en sammenheng med klimaet i klassen, da fokus på mestring vil være viktig for elevenes individuelle fremgang. Et fokus på prestasjon og sosial sammenligning kan være et utgangspunkt for at elevene opplever en tvil om egen kompetanse og følelsen av å mislykkes (Ommundsen, 2006).

Behovet for tilhørighet handler om følelsen av å være tilknyttet andre, bli akseptert av andre og dermed føle en trygghet i sosiale kontekster, både individuelt og i større grupper (Ntoumanis, 2001; Vansteenkiste \& Ryan, 2013). Tilfredstillelse av dette behovet innebærer at individet føler en fortrolighet og ekte tilknytning til andre, mens frustrasjon av behovet skaper en følelse av å bli ekskludert og være ensom. Frustrasjon skapes også ved at individet føler at forholdet til andre er overfladisk (Chen et al., 2015). Større trygghet hos elevene vil trolig skapes hvis læreren skaper et mestringsorientert klima der alle spiller en viktig rolle, og mestring og utvikling kommer foran prestasjoner og konkurranser (Cox \& Williams, 2008).

\section{Innsats}

Innsats i kroppsøving innebærer at eleven prøver og jobber hardt for å løse faglige utfordringer etter beste evne, uten å gi opp. Innsats vurderes også som elevenes evne til å vise selvstendighet i kroppsøving, og at de utfordrer egen fysisk kapasitet, samtidig som de viser sterkt fokus og et ønske om å lære (Utdanningsdirektoratet, 2012). Aasland og Engelsrud (2017) peker på at innsats er noe kroppsøvingslærere «lett kan se» gjennom at elevene blir drivende svette, viser framgang og har god innstilling, og at de i lagspill spiller andre gode. Innsats og innsatsregulering har betydning for eleven med tanke på å nå sine studiemål ved å fokusere på å fullføre oppgavene, selv om de ikke liker oppgavene eller ser dem som interessante (Pintrich et. al., 1991).

\section{Indre motivasjon}

Den iboende iveren etter å aktivt utvikle nye ferdigheter, utfordre seg selv og ta interesse i nye aktiviteter, selv i fravær av eksterne belønninger, sees på som indre motivasjon (Ryan \& Deci, 2007). Med indre motivasjon styres atferden av en indre tilstand som er preget av ren interesse og glede av å gjøre noe (Ryan \& Deci, 2000). Aktiviteter i kroppsøving vil være preget av iboende tilfredsstillelse istedenfor eksterne konsekvenser, som for eksempel karakter eller frykt for å få kritikk fra læreren. Ifølge Ryan og Deci, (2000) er indre motivasjon gjennomgripende og viktig for mennesket, da mennesket av natur er nysgjerrige 
og lekne skapninger som søker etter å erfare og lære uten ytre insentiver. Denne naturlige motivasjonen til å gjøre noe, er viktig for menneskets kognitive, sosiale og fysiske utvikling. Adferd som styres av ens iboende interesse er det som utvikler kunnskap og ferdigheter (Ryan \& Deci, 2000). Å skape indre motivasjon blant elever i kroppsøving vil være helt sentralt for at elevene skal få gode opplevelser i kroppsøving.

\section{Motivasjonelt klima og grunnleggende behov}

En viktig faktor i arbeidet med å skape et bestemt motivasjonelt klima, er lærerarbeidet. Læreren planlegger innholdet, grupperer elevene, gir råd, veileder og evaluerer. Motivasjonsklimaet vil påvirke tilfredsstillelse og/eller frustrasjon av de tre grunnleggende psykologiske behovene (Reinboth \& Duda, 2006).

I et mestringsorientert klima fokuseres det på mestring av oppgaver og individuell fremgang hos elevene. Kroppsøvingsfaget blir noe elevene kan få kontroll over, og det vil trolig ha betydning for deres motivasjon og vilje i læringsarbeidet (Ommundsen, 2006). Ifølge Ames (1992a) vil et mestringsorientert klima være viktig for å tilfredsstille de tre grunnleggende psykologiske behovene og dermed også skape en mer selvbestemt motivasjon. Ames (1992a) hevder også at selvoppfattet kompetanse blomstrer mer i et mestringsorientert klima, enn i et prestasjonsorientert klima. Autonomistøtte er sentralt i et mestringsorientert klima, noe som innebærer å legge vekt på elevenes valg og innflytelse i undervisningen (Ommundsen, 2006). En rekke studier viser at et klima med autonomistøttende tilnærminger fra læreren har en positiv effekt på tilfredsstillelse av alle de tre grunnleggende behovene, indre motivasjon, og innsats (Bartholomew et al., 2011; Gagné, Ryan \& Bargmann, 2003; Hein \& Caune, 2014; Standage, Duda \& Ntoumanis, 2006; Ulstad et al., 2016). Studier viser også at valg og innflytelse i læring av nye aktiviteter og ferdigheter har en signifikant sammenheng med interesse, glede, engasjement og prestasjon (Reeve \& Jang, 2006; Ommundsen \& Kvalø, 2007).

Studier viser at et mestringsorientert klima er viktig for å tilfredsstille de tre grunnleggende behovene, og det har også en positiv effekt på indre motivasjon, innsats og glede (Cecchini et al., 2001; Cox \& Williams, 2008; Reinboth \& Duda, 2006). En studie fra Reinboth og Duda (2006) viste at prestasjonsorientert klima hadde en negativ effekt på tilfredsstillelse av behovet for tilhørighet, men ingen direkte negativ link til behovet for kompetanse og autonomi. For de med gode ferdigheter og høy kompetanse i kroppsøving, kan også behovet for autonomi økes hvis disse får være med å bestemme og styre i større grad enn andre (Reinboth \& Duda, 2006). En kontrollerende lærer med strenge pedagogiske tilnærminger kan knyttes til et prestasjonsorientert klima. Studier av Assor, Kaplan, Kanat-Maymon og Roth (2014) viste en klar sammenheng mellom kontrollerende lærerstil og ytre motivasjon og amotivasjon. En studie på trenere belyser også at en kontrollert stil trigger frustrasjon av behovene (Bartholomew et al., 2011). 


\section{Grunnleggende behov, innsats, indre motivasjon og karakterer}

Tidligere forskning viser at elevenes oppfattelse av hvorvidt læreren legger til rette for tilfredsstillelse av de tre grunnleggende behovene har en positiv effekt på glede og innsats i faget (Zhao \& Li, 2016). Studier av Taylor og Lonsdale (2010) viser en positiv sammenheng mellom tilfredstillelse av behovene og innsats i kroppsøving. Tidligere undersøkelser viser også positive sammenhenger mellom tilfredsstillelse av de tre grunnleggende behovene og indre motivasjon (Standage et al., 2005; Sun \& Chen, 2010). En studie av Ferrer-Caja og Weiss (2000) viste at tilfredsstillelse av behovet for autonomi skapte mer selvbestemt motivasjon.

\section{Problemstilling og hypoteser}

Hvilken sammenheng er det mellom oppfattet motivasjonelt klima og tilfredsstillelse og frustrasjon av de tre grunnleggende psykologiske behovene i kroppsøving, og hvilken sammenheng har tilfredsstillelse og frustrasjon av disse behovene på elevenes innsats, indre motivasjon og karakterer?

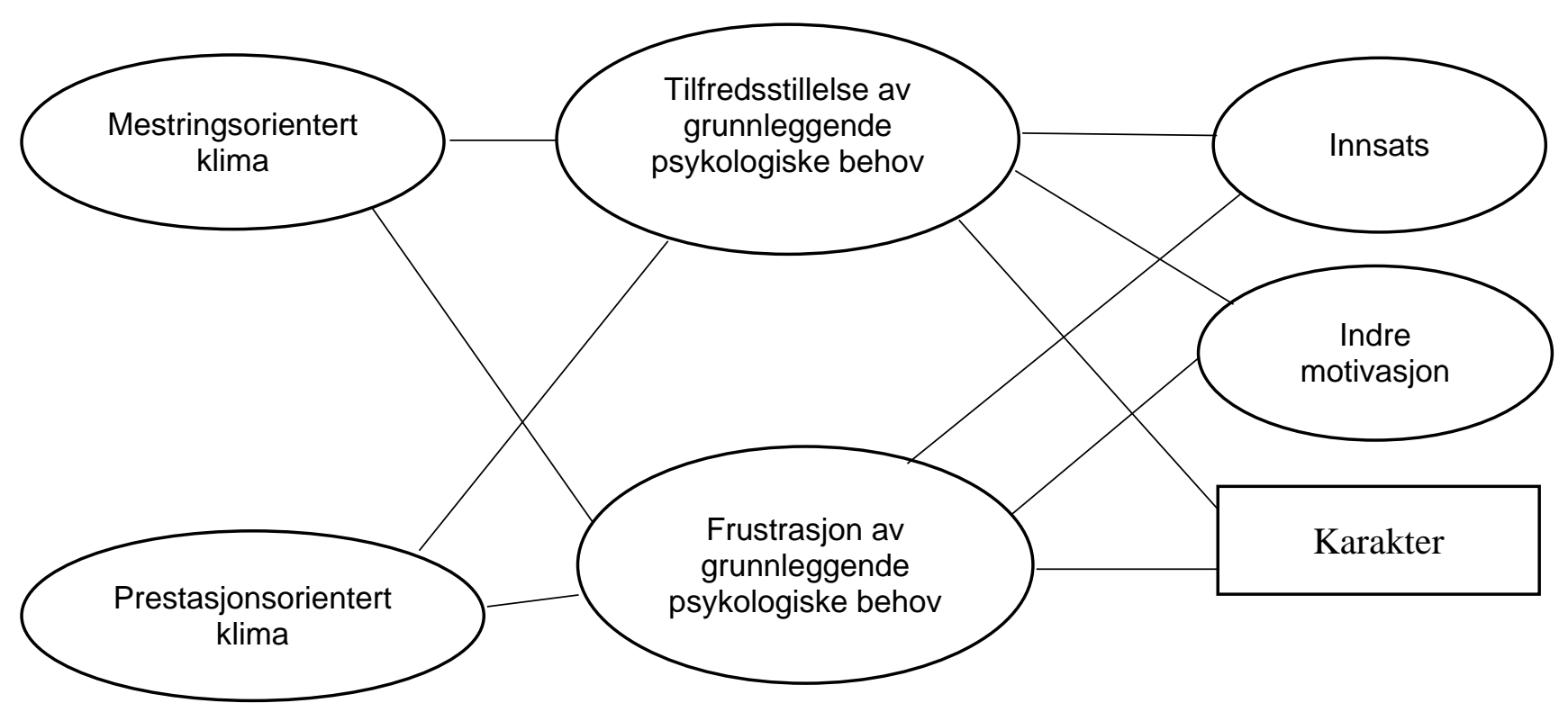

Figur 1. Hypotesemodell

Hypotese 1: Mestringsorientert klima har en positiv sammenheng med tilfredsstillelse av de tre grunnleggende psykologiske behovene.

Hypotese 2: Mestringsorientert klima har en negativ sammenheng med frustrasjon av de tre grunnleggende psykologiske behovene.

Hypotese 3: Prestasjonsorientert klima har en positiv sammenheng med frustrasjon av de tre grunnleggende psykologiske behovene.

Hypotese 4: Prestasjonsorientert klima har en negativ sammenheng med tilfredsstillelse av de tre grunnleggende psykologiske behovene.

Hypotese 5: Tilfredsstillelse av de tre grunnleggende psykologiske behovene har en positiv sammenheng med innsats, indre motivasjon og karakter. 
Hypotese 6: Frustrasjon av de tre grunnleggende psykologiske behovene har en negativ sammenheng med innsats, indre motivasjon og karakter.

\section{Metode}

\section{Populasjon og utvalg}

Undersøkelsen ble gjennomført på fire videregående skoler i Trøndelag. 230 elever deltok, av disse er 137 jenter og 93 gutter. Utvalget fordeler seg på VG1 $(\mathrm{N}=63)$, VG2 $(\mathrm{N}=81)$ og VG3 $(\mathrm{N}=86)$. Det er brukt lukkede spørsmål med svaralternativ. Vi var fysisk tilstede under gjennomføringen av undersøkelsene, og skjemaer og skrivesaker ble utdelt til respondentene. Undersøkelsens formål og tema ble også kort forklart før undersøkelsen startet.

\section{Måleinstrumenter}

I spørreundersøkelsen ble det brukt innledende spørsmål om kjønn, klasse, og karakter siste termin i kroppsøving. Spørreundersøkelsen besto av tre ulike spørreskjemaer. Alle tre spørreskjemaene hadde en fempunktsskala, enten fra «aldri» til «alltid» eller fra «ikke sant i det hele tatt» til «veldig sant». I forkant av undersøkelsen ble spørreskjemaene testet på ni elever på VG1. Dette ble gjort for å avdekke tidsbruk og eventuelle mangler og uklarheter ved spørsmålene.

Motivasjonelt klima ble målt med The Perceived Motivational Climate in Sport Questionnaire-2 (PMCSQ-2) (Newton \& Duda, 1993). Dette spørreskjemaet er hovedsakelig brukt i idrettssammenheng, og består av 30 spørsmål. Eksempel på spørsmål er; «I min kroppsøvingsklasse blir en oppfordret til å gjøre sitt beste» (mestringsklima), og «I min kroppsøvingsklasse er en redd for å gjøre feil» (prestasjonsklima). Spørsmålene ble tilpasset konteksten kroppsøving der innledningen i spørsmålsformuleringen ble byttet fra «i min idrett», til «i min kroppsøvingsklasse».

Grunnleggende psykologiske behov ble målt med Basic Psychological Need Satisfaction and Frustration Scale (BPNSFS) (Chen et al., 2015). Dette spørreskjemaet består av 24 spørsmål. Eksempel på spørsmål er; «Jeg føler meg veldig fortrolig med de andre i kroppsøving» (tilfredsstillelse av behovet for sosiale relasjoner), og «Jeg er skuffet over mange av mine prestasjoner i kroppsøving» (frustrasjon av behovet for kompetanse). Spørsmålene ble oversatt fra engelsk til norsk og tilbake igjen etter Beaton et al.,(2000).

Innsats ble målt med Motivated Strategies for Learning Questionnaire (MSLQ) (Pintrich et al., 1991). Dette spørreskjemaet består av 4 spørsmål. Eksempel på spørsmål er; «Selv når oppgavene er kjedelige og uinteressante, klarer jeg å fortsette å jobbe til jeg er ferdig.» Indre motivasjon ble målt med Intrinsic Motivation Inventory (IMI) (McAuley, Duncan \& Tammen, 1989), som består av 10 spørsmål. Eksempel på spørsmål er; «Jeg liker kroppsøving veldig mye». IMI er brukt i tidligere forskning, blant annet Goudas og Biddle (1994), og 
MSLQ er oversatt til norsk og tidligere brukt i forskningsprosjekt knyttet til norsk skole (Ulstad et al., 2016).

\section{Analyse av undersøkelsen}

Alle besvarte spørreskjema ble plottet i SPSS 25. Totalt 7 variabler blir brukt i videre analyse av resultatene. Cronbach alpha ble undersøkt for å vurdere reliabiliteten på variablene. Med et utvalg på over 200 settes grensen på .70, men verdier ned mot .65 kan regnes som tilfredsstillende (Ponterotto \& Ruckdeschel, 2007). Pearsons korrelasjonsanalyse ble brukt for å utrykke relasjonen mellom variablene og en SEM-analyse ble gjennomført for å teste hypotesene og indirekte effekter. Mplus versjon 8.3 ble brukt for å kjøre SEM-analyse (Muthen \& Muthen, 1998 - 2017). Etter å ha kjørt SEM-analysen, får en oppgitt ulike FIT-verdier. Disse verdiene indikerer hvor godt den empiriske modellen passer med den teoretiske modellen. Comparative Fit Index (CFI) og Tucker-Lewis Index (TLI) bør være over .90, og Root Mean Square of Approximation (RMSEA) bør være under .05 for optimal fit, og under .10 for akseptabel fit (Brown \& Cudeck, 1993).

\section{Resultater}

\section{Deskriptiv statistikk}

Tabell 1. Deskriptiv statistikk, Pearson korrelasjonsanalyse mellom variablene og Cronbach alphaverdier (uthevet skrift).

\begin{tabular}{|l|l|l|l|l|l|l|l|l|}
\hline Variabler & $\mathrm{M}$ & $\mathrm{SD}$ & 1 & 2 & 3 & 4 & 5 & 6 \\
\hline 1. Mestringsorientert klima & 3.83 & 0.52 & $\mathbf{. 9 0}$ & & & & & \\
\hline 2. Prestasjonsorientert klima & 2.07 & 0.55 & $-.46^{* *}$ & $\mathbf{. 8 7}$ & & & & \\
\hline 3. Tilfredsstillelse behov & 3.78 & 0.64 & $.64^{* *}$ & $-.38^{* *}$ & $\mathbf{. 8 5}$ & & & \\
\hline 4. Frustrasjon behov & 2.18 & 0.70 & $-.46^{* *}$ & $.51^{* *}$ & $-.74^{* *}$ & $\mathbf{. 8 5}$ & & \\
\hline 5. Innsats & 4.22 & 0.74 & $.24^{* *}$ & $-.16^{*}$ & $.50^{* *}$ & $-.45^{* *}$ &. $\mathbf{6 7}$ & \\
\hline 6. Indre motivasjon & 4.31 & 0.90 & $.40^{* *}$ & $-.24^{* *}$ & $.72^{* *}$ & $-.60^{* *}$ & $.55^{* *}$ & $\mathbf{. 9 6}$ \\
\hline 7. Karakter & 4.68 & 0.76 & $.33^{*}$ & -.12 & $.45^{* *}$ & $-.28^{* *}$ & $.41^{* *}$ & $.47^{* *}$ \\
\hline
\end{tabular}

$* * \mathrm{p}<0,01, * \mathrm{p}<0,05$.

Tabell 1 viser Cronbach alpha-verdiene (uthevet skrift) for de ulike variablene. Verdiene er tilfredsstillende for alle variablene med unntak av tilhørighet med en verdi på ,64 (Ponterotto \& Ruckdeschel, 2007).

\section{Pearsons korrelasjonsanalyse}

I tabell 1 fremstilles korrelasjonsverdiene på de sju ulike variablene i hypotesemodellen (Figur 1). Resultatene støtter hypotesene.

\section{SEM-analyse}

Det ble testet seks målemodeller der det ble gjort enkelte endringer for å forbedre fit. Endringene baserer seg i hovedsak på lave faktorladninger og forslag ut fra 
«modification indices» i Mplus i forhold til kovariasjon mellom spørsmål. Endringer i modellen er basert på en teoretisk begrunnelse. Mestringsklima hadde RMSEA; .08, CFI; .92, TLI; .90. På grunn av kovariasjon mellom enkelte spørsmål ble det valgt å legge inn kovariasjon mellom to sett med spørsmål som var veldig likt formulert. Dette ga RMSEA; .07, CFI; .94, TLI; 93. Prestasjonsklima hadde RMSEA; .12, CFI; .83, TLI; .79. På grunn av lav faktorladning på enkelte spørsmål ble 2 spørsmål fjernet fra variabelen. Disse spørsmålene hadde ord i seg som kan oppfattes ulikt fra elev til elev. I tillegg ble kovariasjon lagt inn mellom to sett med spørsmål. Dette ga RMSEA; .09, CFI; .92, TLI; .90. Tilfredsstillelse av behov hadde RMSEA; .10, CFI; .87, TLI; .86. Her ble to spørsmål som måler hvert av de tre behovene korrelert, og ett spørsmål som måler sosiale relasjoner ble tatt ut. Spørsmålet handlet om at man føler seg knyttet til personer i klassen som man ser på som viktige. Dette trenger ikke gjelde på videregående da dine venner kan gå i andre klasser. Disse endringene ga RMSEA; .05, CFI; .98, TLI; .97. Frustrasjon av behov hadde RMSEA; .12, CFI; .83, TLI; .79. Her ble ett spørsmål fjernet, som måler frustrasjon av autonomi. Dette spørsmålet hadde en formulering som var ulikt de andre spørsmålene. I tillegg ble to spørsmål som måler sosiale relasjoner og to som måler autonomi korrelert. Dette ga RMSEA; .09, CFI; .91, TLI; .88. Indre motivasjon hadde RMSEA; .15, CFI; .95, TLI; .93. Her ble ett spørsmål fjernet og tre par med spørsmål ble korrelert. De korrelerte spørsmålene var ganske likt formulert og spørsmålet som ble fjernet var ett av de som var reversert og kunne oppfattes feil av elevene. Dette ga; RMSEA; .07, CFI; .99, TLI; .99. Innsats hadde RMSEA; .13, CFI; .96, TLI; .88. Her ble ett spørsmål tatt ut som skulle måle om de jobbet hardt selv om de ikke likte det de skulle gjøre. Dette spørsmålet kan tolkes feil av de som mener de liker det meste i kroppsøving. Dette ga; RMSEA; .00, CFI; 1.0, TLI; 1.0. En samla målemodell med alle variablene etter endringer ga; RMSEA; .06, CFI; .86, TLI; .86. Oversikt over SEM - analysen med de sju variablene er å finne i figur 2. I tillegg gir tabell 2 en oversikt over signifikante indirekte effekter mellom motivasjonelt klima og innsats, indre motivasjon og karakterer, med behov som mediatorer. Resultatene i figur 2 viser en signifikant og positiv sammenheng mellom et mestringsorientert klima og tilfredsstillelse av de tre grunnleggende behovene samlet, mens det er en negativ signifikant sammenheng mellom mestringsklima og frustrasjon av behovene. Resultatene støtter hypotese 1 og 2. SEM-analysen viser også en negativ sammenheng mellom et prestasjonsorientert klima og tilfredsstillelse av behovene. Dette støtter hypotese 4. Figur 2 viser en positiv og signifikant sammenheng mellom et prestasjonsorientert klima og frustrasjon av behovene, noe som samsvarer med hypotese 3. Det motivasjonelle klimaet forklarer $30 \%$ av variasjonen i tilfredsstillelse av de tre grunnleggende behovene, mens det forklarer $31 \%$ av variasjonen i frustrasjon av behovene. 


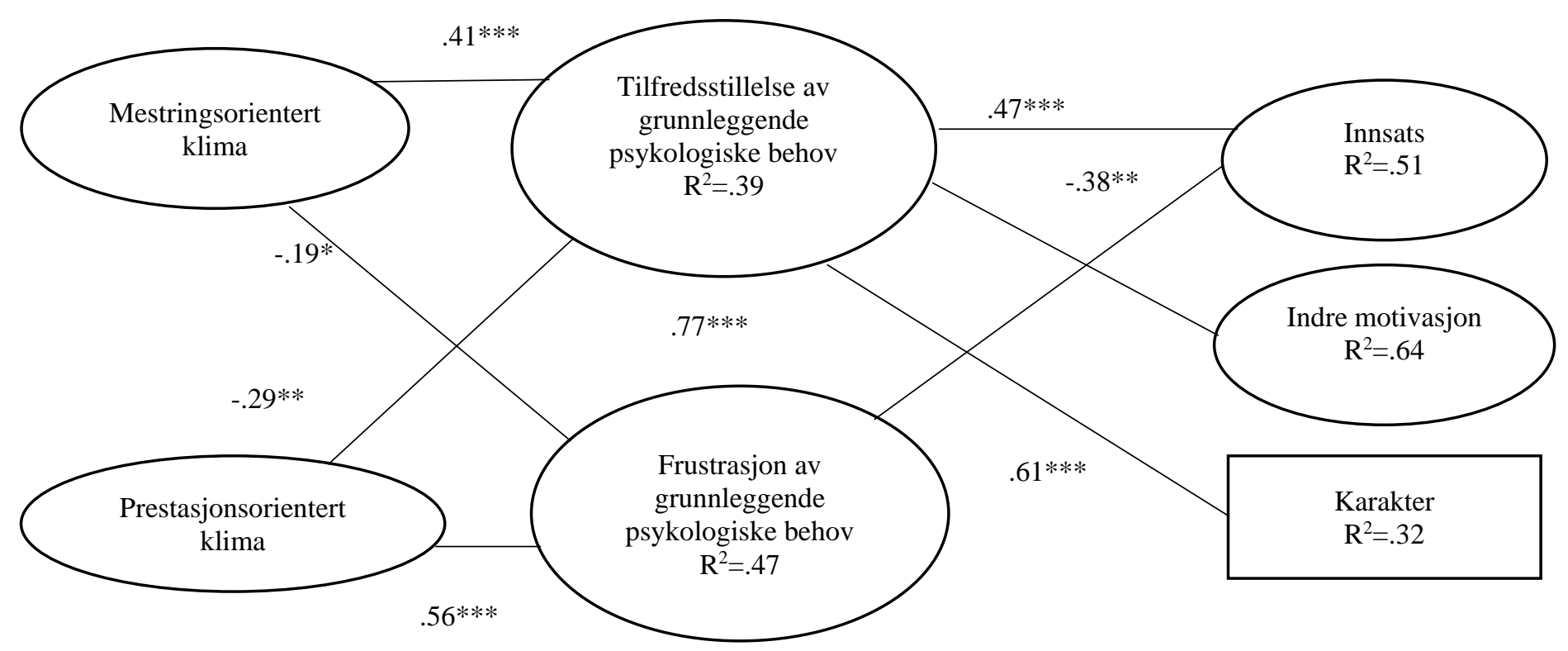

Figur 2. SEM-analyse med standardiserte betakoeffisienter. RMSEA; .060 (.057 - .064), CFI; .85,

TLI; .85, SRMR; .09, *** $\mathrm{p}<0.001,{ }^{* *} \mathrm{p}<0.01, * \mathrm{p}<0.05$.

Videre viser resultatene en klar positiv og signifikant sammenheng mellom tilfredsstillelse av de tre behovene og innsats, indre motivasjon og karakter. Alle disse resultatene samsvarer med hypotese 5 . Resultatene viser også en negativ og signifikant sammenheng mellom frustrasjon av de tre grunnleggende behovene og innsats. Sammenhengen mellom frustrasjon av behovene og karakter og indre motivasjon er ikke signifikant, og hypotese 6 blir delvis støttet. Motivasjonelt klima og tilfredsstillelse og frustrasjon av behovene forklarer $51 \%$ av variasjonen i innsats, $64 \%$ av variasjonen i indre motivasjon og $32 \%$ av variasjonen i karakter. Når modellen ble testet som en strukturmodell fikk vi følgende fit verdier $\left(\mathrm{X}^{2}=2695.34, \mathrm{df}=1461, \mathrm{p}<, 001\right.$, RMSEA; .060 (.057 - .064), CFI; .85, TLI; .85, SRMR; .09). Verdiene for RMSEA er innenfor anbefalt grense, mens verdiene for CFI og TLI er noe under anbefalt grense. Dette kan ha noe å gjøre med at vi har noen lave faktorladninger (ned mot 0.50), og en ganske kompleks modell i forhold til størrelsen på utvalget. CFI og TLI har en tendens til å synke når man øker antallet variabler i modellen (Kenny \& McCoach, 2003). Alle indirekte effekter med bakgrunn i figur 2 ble testet og det ble funnet signifikante indirekte effekter fra mestringsklima via tilfredsstillelse av behov til både innsats, indre motivasjon og karakterer. Fra prestasjonsklima ble det funnet signifikante negative indirekte effekter til innsats via både tilfredsstillelse av behov, og frustrasjon av behov, og til indre motivasjon via tilfredsstillelse av behov. 
Tabell 2. Test av indirekte effekter mellom læringsklima og læringsindikatorene med behov som mediator. Bare signifikante effekter er med i tabellen.

\begin{tabular}{|l|l|l|l|l|}
\hline Uavhengig variabel - Mediator - Avhengig variabel & Estimater & SE & EST/SE & Signifikantnivå \\
\hline $\begin{array}{l}\text { Mestringsklima - Tilfredsstillelse av behov - Indre } \\
\text { motivasjon }\end{array}$ & .52 & .123 & 4.20 & .000 \\
\hline Mestringsklima - Tilfredsstillelse av behov - Karakter & .31 & .090 & 3.38 & .001 \\
\hline Mestringsklima - Tilfredsstillelse av behov - Innsats & .28 & .059 & 1.79 & .001 \\
\hline Prestasjonsklima - Frustrasjon av behov - Innsats & -.20 & .071 & -2.84 & .004 \\
\hline Prestasjonsklima - Tilfredsstillelse av behov - Innsats & -.13 & .051 & -2.53 & .012 \\
\hline $\begin{array}{l}\text { Prestasjonsklima - Tilfredsstillelse av behov - Indre } \\
\text { motivasjon }\end{array}$ & -.23 & .078 & -2.98 & .003 \\
\hline
\end{tabular}

\section{Diskusjon}

Ett av hovedpoengene i denne studien er å se på klimaets betydning for elevenes innsats, indre motivasjon og karakterer i kroppsøvingsundervisningen. Analyser viser at et mestringsorientert klima har en indirekte positiv sammenheng med indre motivasjon, innsats og karakterer via tilfredsstillelse av behovene. Dette samsvarer med tidligere forskning gjort av Ferrer-Caja og Weiss (2000). Disse funnene viser den positive effekten som ligger i et mestringsklima når det gjelder å påvirke viktige suksesskriterier i kroppsøving. Analyser viser også at et prestasjonsorientert klima har en indirekte negativ sammenheng med innsats via frustrasjon av behov, og en negativ sammenheng med indre motivasjon via dekking av behov. Dette er nye funn, og viser de negative påvirkningene et prestasjonsklima kan ha på elever i kroppsøving på videregående skole.

Videre blir det viktig å se på sammenhengen mellom motivasjonelt klima og tilfredsstillelse av behovene, og spesielt frustrasjon av behov $\mathrm{i}$ en kropsøvingskontekst, da dette tidligere ikke er blitt undersøkt. Resultatene i denne undersøkelsen viser en signifikant positiv sammenheng mellom et mestringsorientert klima og tilfredsstillelse av autonomi, kompetanse og tilhørighet for elever på studiespesialiserede linje i videregående skole. Disse positive funnene samsvarer med tidligere forskning som sier at et mestringsorientert klima er viktig for å tilfredsstille de tre behovene (Cecchini et al., 2001; Cox \& Williams, 2008; Reinboth \& Duda, 2006), og underbygger også tidligere forskning om autonomistøtte i undervisningen (Bartholomew et al., 2011; Gagné et al., 2003; Hein \& Caune, 2014; Standage et al., 2006; Ulstad et al., 2016). Når det gjelder sammenhengen mellom mestringsklima og frustrasjon av behovene, så viser denne studien til en negativ sammenheng. Resultatene i denne undersøkelsen viser også en positiv sammenheng mellom et prestasjonsorientert klima og frustrasjon av behovene, og signifikante negative funn mellom et prestasjonsorientert klima og tilfredsstillelse av behovene. Disse signifikante sammenhengene som kobler prestasjonsklima til behovstilfredsstillelse og behovsfrustrasjon i en kroppsøvingskontekst er nye, da tidligere forskning på dette området er gjort mellom en kontrollerende lærerstil 
og frustrasjon av behovene (Assor et al., 2014; Bartholomew et al., 2011). I denne studien viser vi til en negativ sammenheng knyttet til alle de tre behovene for autonomi, kompetanse og sosiale relasjoner. Summen av signifikante sammenhenger i forholdet mellom motivasjonelt klima og tilfredsstillelse og frustrasjon av behovene for autonomi, kompetanse og sosiale relasjoner i kroppsøving underbygger sterkt viktigheten av å vektlegge det å fremme et mestringsklima fremfor et prestasjonsklima.

Videre viser resultatene en signifikant positiv sammenheng mellom tilfredsstillelse av de tre behovene og innsats, indre motivasjon og karakter blant elever på studiespesialiserende linje på videregående skole. Dette samsvarer med tidligere forskning som viser positive sammenhenger mellom tilfredsstillelse av behovene og innsats, indre motivasjon og karakter (Bagøien et al., 2010; Goudas \& Biddle, 1994; Krijgsman et al., 2017; Standage et al., 2005; Taylor \& Lonsdale, 2010; Sun \& Chen, 2010).

Undersøkelsen viser en signifikant negativ sammenheng mellom frustrasjon av de tre grunnleggende behovene og innsats. Analysene viser ingen signifikante funn mellom frustrasjon av behovene og karakter i faget. Dette samsvarer med tidligere forskning på området (Assor et al., 2014; Bartholomew et al., 2011; Chen et al., 2015).

\section{Praktiske og pedagogiske implikasjoner i kroppsøving}

Undersøkelsen viser at elever på studiespesialiserende linje i videregående skole oppfatter klimaet i kroppsøvingsklassen sin som mer mestringsorientert enn prestasjonsorientert (Tabell 1). Resultatene belyser betydningen av å skape et mestringsorientert klima fremfor et prestasjonsorientert klima. Det klimaet læreren fremmer vil være avgjørende for elevenes tilfredsstillelse og frustrasjon av grunnleggende behov i kroppsøving og ha indirekte betydning for elevenes innsats, indre motivasjon og karakterer. Å ha klare pedagogiske tilnærminger om at alle i en kroppsøvingsklasse har en like betydningsfull rolle kan være starten på å bygge et mestringsorientert klima.

Et mestringsorientert klima er opptatt av mestring og utvikling fremfor prestasjon og sosial sammenligning. Resultatene i denne undersøkelsen viser at behovet for kompetanse tilfredsstilles i størst grad. Da er det viktig at læreren i klassen gir likeverdig anerkjennelse og oppmerksomhet til alle elevene, uavhengig av ferdigheter og kompetanse (Ames, 1992a). Hvis individuell evaluering er fraværende, og tilbakemeldinger gis nærmest ubevisst og helt uten mål og mening fra læreren, vil en frustrere behovet for kompetanse. Henger evalueringene og tilbakemeldingene sammen med en autoritær lærerstil, og det skjer i klassens offentlighet, kan enkelte elever oppfatte at læreren fokuserer på prestasjon, konkurranse og sosial sammenligning med andre (Ames, 1992a). Det blir viktig å kjenne elevene sine godt og skape gode relasjoner. Å sette av tid før og etter undervisning for en faglig samtale, eller gi skriftlige tilbakemeldinger gjennom skoleåret, kan være hensiktsmessige metoder. 
Når prøving og feiling blir en helt naturlig del av klimaet i kroppsøvingsklassen, er det grunn til å tro at flere elever opplever klimaet som mer betryggende. Elevene får en følelse av at de kan mislykkes i aktivitetene, uten at læreren lar det få noen negative konsekvenser (Ommundsen, 2006). Da vil det være større sannsynlighet for at elevene tilfredsstiller de grunnleggende behovene, som vil føre til større trivsel, og bedre selvfølelse (Cheon et al., 2014; Vansteenkiste \& Ryan, 2013). Noen av aktivitetene som læreren legger opp til og gjennomfører i en kroppsøvingstime kan være basert på konkurranse. Det kan være ulike kamper, stafetter, leker eller fysiske tester. Her blir det viktig at konkurranseaktiviteten holdes på et nivå der elevene får mulighet til å mestre og oppleve glede. Overgangen mellom de positive og negative konsekvensene i slike konkurransepregede aktiviteter er kort, noe som gjør at læreren må trå forsiktig og kjenne elevene sine. Hvis det å vinne betyr mest, og læreren er opptatt av konkurranse, vil etiske normer legges til side, og juks og uetisk opptreden blir lettere akseptert (Ommundsen, 2006). Derfor bør det å bare gi anerkjennelse til de som mestrer på et høyt nivå, og gruppere ut i fra ferdigheter, unngås (Ommundsen, 2006).

Denne undersøkelsen viser at behovet for autonomi, kompetanse og tilhørighet blir tilfredsstilt i adskillig større grad enn frustrert. Dette er i samsvar med Chen et al. (2015). Resultatene underbygger betydningen av å tilfredsstille de tre behovene for autonomi, kompetanse og tilhørighet i kroppsøvingsfaget. Behovene er også viktig i forhold til å påvirke elevenes innsats, indre motivasjon og karakterer.

Menneskets indre behov for å oppnå og utvikle egen kompetanse er viktig (Strandkleiv, 2006). I mangfoldet av forutsetninger, kompetanse og ferdigheter i klassen, er det viktig å drive en tilpasset opplæring. Da kan læreren sørge for at kroppsøving blir et fag hvor alle får mulighet til å oppnå kompetanse (Utdanningsdirektoratet, 2015). Da er konkrete tilbakemeldinger viktig i elevenes utvikling, og individuelle opplegg kan være en mulig metode (Ames, 1992a). Kroppsøving er et veldig «synlig» fag. Dette kan være en forklaring på graden av selvoppfattet kompetanse, og der elevenes tvil om egen kompetanse og følelsen av å mislykkes vil frustrere behovet for kompetanse. Sett i sammenheng med klimaet i klassen, er det viktig at læreren ikke setter for høye krav og forventninger ut i fra hver enkelt sine forutsetninger. Dette kan virke truende for elevene (Ommundsen, 2006), og da vil ikke bare den selvoppfattede kompetansen svekkes, men også indre motivasjon og innsats (Ommundsen \& Kvalø, 2007).

Behovet for tilhørighet tilfredsstilles i stor grad i denne undersøkelsen, og er også det behovet som skårer lavest på frustrasjon. Deci og Ryan (2000) fremhever viktigheten av tilfredsstillelse av tilhørighet for indre motivasjon. For elever som ikke finner aktivitetene i kroppsøving interessante, er betydningen av å føle seg tilknyttet andre elever viktig for et høyt aktivtetsnivå og innsats i undervisningen (Deci \& Ryan, 2000). Flere studier fremmer viktigheten av at elevene opplever 
trygghet og gode relasjoner med medelevene sine i en kroppsøvingsklasse (Ntoumanis, 2001; Vansteenkiste \& Ryan, 2013; Ryan \& Deci, 2017).

Læreren kan legge til rette for å tilfredsstille dette behovet ved å oppmuntre elevene til å løfte hverandre opp og spille hverandre gode (Utdanningsdirektoratet, 2015). Elevene kan vise forskjellig grad av oppløftende atferd ovenfor medelever, blant annet basert på om de er opptatt av å prestere og vinne, eller å mestre og utvikle seg (Holstad, 2012). Å utøve fair play er en del av kompetansemålene i kroppsøving, og er et naturlig fokus i kroppsøvingstimen. En sterkere lagånd og gode relasjoner mellom elevene i klassen kan sørge for at flere føler seg trygge til å utfolde seg i faget. Læreren bør også legge vekt på relasjonene han/hun har til elevene, da følelsen av trygghet og aksept ovenfor læreren i klasserommet er viktig (Deci \& Ryan, 2000). Hvis eleven føler seg ekskludert og ensom i kroppsøvingsklassen frustreres behovet for tilhørighet. Resultatene i denne undersøkelsen indikerer at dette kan ha en negativ effekt på elevenes indre motivasjon og innsats. Læreren må jobbe målrettet for å se hver enkelt elev og bidra til at de føler en trygghet og fortrolighet med andre. Et svært positivt funn i denne undersøkelsen er at elever på studiespesialiserende linje i videregående skole i veldig liten grad opplever frustrasjon av behovet for tilhørighet. Med en sterk tilhørighet i kroppsøvingsklassen vil elevene i stor grad oppleve indre motivasjon (Standage et al., 2005; Sun \& Chen, 2010). Med mer indre motivasjon finner trolig også elevene grunn for høyere innsats og får en bedre selvoppfattet kompetanse i faget (Ntoumanis, 2001; Zhang, 2009).

Det kan være flere grunner til at autonomi er et behov det er vanskelig å tilfredsstille blant elevene. I læreplanen for kroppsøving er det klare retningslinjer for hva kroppsøvingsfaget skal bidra til, og hva elevene skal lære seg (Utdanningsdirektoratet, 2015). Rammene som settes, store klasser og få ressurser kan hindre autonomi. En viktig del av kompetansemålene er at de selv skal planlegge, gjennomføre og evaluere egentrening og friluftslivsopplegg (Utdanningsdirektoratet, 2015). Det er viktig at læreren legger til rette for at lærerstyrte aktiviteter også baserer seg på elevenes ønsker og behov (Ames, 1992a).

Konklusjon

Målet med denne undersøkelsen var å undersøke sammenhengen mellom oppfattet motivasjonelt klima og de tre grunnleggende behovene, samt se på sammenhengen mellom tilfredsstillelse og frustrasjon av behovene i forhold til innsats, indre motivasjon og karakterer. Resultatene gir grunn til å konkludere med at hvis læreren arbeider med å skape et mestringsorientert klima vil det legges til rette for tilfredsstillelse av behovene for autonomi, kompetanse og tilhørighet hos elevene. Et prestasjonsorientert klima vil i større grad bidra til frustrasjon av de grunnleggende behovene, og samtidig bidra til mindre tilfredsstillelse av 
behovene. Videre vil mer frustrasjon av behovene ha en negativ effekt på innsats og indre motivasjon. Klimaet som skapes i kroppsøvingsundervisningen viser seg å ha indirekte betydning for elevenes karakterer, innsats og indre motivasjon gjennom tilfredsstillelse og frustrasjon av behovene for autonomi, kompetanse og sosiale relasjoner.

Studien har sine begrensninger når det kommer til størrelsen på utvalget som er undersøkt. Med et utvalg på 230, og et lite antall skoler, kan man stille spørsmål ved representativiteten til utvalget. Problemer med fit i SEM-analysen er også en utfordring knyttet til analysen av dataene. Enkelte endringer er gjort i måleinstrumentene for å forbedre fit. Endingene baserer seg i hovedsak på lave faktorladninger og kovariasjon mellom enkeltspørsmål. For å sikre at resultatene skal være gyldige etter endringene er gjort, ligger det en teoretisk begrunnelse til grunn. I tillegg er det metodisk argumentert for årsaker til problemer med fit i resultatkapittelet. Studien er også en tverrsnittsstudie. Noe som gjør at vi ikke kan si noe om endringer som skjer over tid på de ulike variablene, og kausalitet $\mathrm{i}$ forholdet mellom variablene. Dette hadde vært interessant å undersøkt i senere studier.

\section{Om forfatterne}

Svein Olav Ulstad er førsteamanuensis ved Nord universitet. Hans forskningsinteresser er krøppsøving, skole, friluftsliv og motivasjonspsykologi. Institusjonstilknytning: Fakultet for lærerutdanning og kunst- og kulturfag, Nord universitet, Høgskoleveien 27, 7600 Levanger

E-post: svein.o.ulstad@nord.no

Vegard Rønning Valstadsve er tidligere masterstudent ved Nord universitet. Institusjonstilknytning: Fakultet for lærerutdanning og kunst- og kulturfag, Nord universitet, Høgskoleveien 27, 7600 Levanger

E-post: vegard_ronval@hotmail.com

Knut Skjesol er førstelektor ved Nord universitet. Hans forskningsinteresser er kroppsøving, skole og motivasjonspsykologi.

Institusjonstilknytning: Fakultet for lærerutdanning og kunst- og kulturfag, Nord universitet, Høgskoleveien 27, 7600 Levanger

E-post: knut.skjesol@nord.no 


\section{Referanser}

Aasland, E. \& Engelsrud, G. (2017). ”Det er lett å se hvem av dere som har god innsats». Om elevers innsats og lærerens blikk i kroppsøving. Journal for Research in Arts and Sports Education, 1(3), 5-17. doi.org/10.23865/jased v1.889

Ames, C. (1992a). Classrooms: Goals, Structures, and Student Motivation. Journal of Educational Psychology, 84(3), 261-271.

Ames, C. (1992b). Achievement goals and the classroom motivational climate. In J. Meece \& D. Schunk (Eds.) Students `perceptions in the classroom: Causes and consequences, 327348. Hillsdale, NJ:Erlbaum.

Ames, C. (1992c). Achievement goals, motivational climate, ans motivational processes. In G.C. Roberts (Ed.) Motivation in sport and exercise, 161-176. Champaign, IL: Human Kinetics.

Assor, A., Kaplan, H., Kanat-Maymon, Y. \& Roth, G. (2014). Directly controlling teacher behaviors as predictors of poor motivation and engagement in girls and boys: The role of anger an anxiety. Learning and Instruction, 15, 397-413. doi: 10.1016/j.learninstruc.2005.07.008

Bagøien, T. E., Halvari, H. \& Nesheim, H. (2010). Self-determined motivation in physical education and its links to motivation for leisure-time physical activity, physical activity, and well-being in general. Perceptual and Motor Skills, 111(2), 407-432. doi: 10.2466/06.10.11.13.14.PMS.111.5.

Bartholomew, K. J., Ntoumanis, N., Ryan, R. M., Bosch, J. A. \& Thøgersen-Ntoumani, C. (2011). Self-determination theory and diminished functioning: the role of interpersonal control and psychological need thwarting. Personality and Social Psychology Bulletin, 37(11), 1459-1473. doi: 10.1177/0146167211413125.

Beaton, D. E., Bombardier, C., Guillemin, F. \& Ferraz, M. B. (2000). Guidlines for the process of cross-cultural adaption of self-report measures. SPINE, 25(24), 3186-3191. http://dx.doi.org/10.1097/00007632-200012150-00014

Biddle, S.J.H. (2001). Enhancing motivation in physical education. In G. C. Roberts (Ed.) Advances in motivation in sport and exercise, 101 - 107. Champaign, IL: Human Kinetics.

Browne, M. W. \& Cudeck, R. (1993). Alternative ways of assessing model fit. In K. A. Bollen \& J. S. Long, Testing structural models (pp. 136-162). London: Sage.

Cecchini, J. A., González, C., Carmona, Á. M., Arruza, J., Escartí, A. \& Balagué, G. (2001). The Influence of the Physical Education Teacher on Intrinsic Motivation, SelfConfidence, Anxiety, and Pre- and Post-Competition Mood States. European Journal of Sport Science, 1(4), 1-11. doi: 10.1080/17461390100071407

Chen, B., Vansteenkiste, M., Beyers, W., Boone, L., Deci, E. L., Duriez, B. \& Verstuyf, J (2015). Basic psychological need satisfaction, need frustration, and need strength across four cultures. Motivation and Emotion, 39, 216-236. doi: 10.1007/s11031-014-9450-1

Cheon, S. H., Reeve, J., Yu, T. H. \& Jang, H. R. (2014). The Teacher Benefits From Giving Autonomy Support During Physical Education Instruction. Journal of Sports \& Exercise Psychology, 36, 331-346.

Cordeiro, P., Paixão, P., Lens, W., Lacante, M. \& Luyckx, K. (2016). The Portuguese Validation of the Basic Psychological Need Satisfaction and Frustration Scale: Concurrent and Longitudinal Relations to Well-being and Ill-being. Psychologica Belgica, 56(3), 193-209. doi: 10.5334/pb.252

Cox, R. H. (2007). Sport psychology: Concepts and Applications. (6th.ed.). England: McGraw Hill. 
Cox, A. \& Williams, L. (2008). The Roles of Perceived Teacher Support Motivational, Climate, and Psychological Need Satisfaction in Student's Physical Education Motivation. Journal of Sport \& Exercise Psychology, 30, 222-239.

Deci, E. L. \& Ryan, R. M. (2000). The "What" and "Why" of Goal Pursuits: Human Needs and the Self-Determination of Behavior. Psychological Inquiry, 11(4), 227-268. doi: 10.1207/S15327965PLI1104_01

Deci, E. L. \& Ryan, R. M. (2002). Handbook of Self-Determination Research. New York: The University of Rochester Press.

Epstein, J. (1988). Effective schools or students? Dealing with diversity. In R. Haskins \& B. Macrae (Eds.) Policies for American`s public schools, 89-126. Norwood, NJ: Ablex.

Epstein, J. (1989). Family structures and student motivation: A developmental perspective. In C. Ames \& R. Ames (Eds.). Research on motivation in education. Vol. 3, 259-295. New York: Academic Press.

Ferrer-Caja, E. \& Weiss, M. R. (2000). Predictors of Intrinsic Motivation Among Adolescent Students in Physical Education. Research Quarterly for Exercise and Sport, 71(3), 267279. doi: 10.1080/02701367.2000.10608907

Gagné, M., Ryan, R. M. \& Bargmann, K. (2003). Autonomy Support and Need Satisfaction in the Motivation and Well-Being of Gymnasts. Journal of Applied Sport Psychology, 15, 372-390. doi: 10.1080/10413200390238031

Goudas, M. \& Biddle, S. (1994). European Journal of Psychology of Education, 9: 241. https://doi.org/10.1007/BF03172783

Helsedirektoratet (2016). Anbefalinger fysisk aktivitet. Hentet fra https://helsedirektoratet.no/folkehelse/fysisk-aktivitet/anbefalinger-fysisk-aktivitet

Hein, V. \& Caune, A. (2014). Relationships between perceived teacher's autonomy support, effort and physical self-esteem. Kinesiology, 46(2), 218-226.

Holstad, H. (2012). Fråfall i kroppsøving, motivasjon og motivasjonelt klima: Ei kvalitativ undersøking om ei gruppe elevar sitt fråfall i kroppsøvingsfaget. Mastergradsavhandling, Høgskolen i Nord-Trøndelag, Levanger.

Kenny, D. \& McCoach, D. (2003). Effect of the number of variables om measures of fit in structural equation modeling. Structural Equation Modeling: A Multidiciplinary Joural, 10(3), 333-351. http://dx.doi.org/10.1207/S15328007SEM1003_1

McAuley, E., Duncan, T. \& Tammen, V. V. (1989). Psychometric properties of the Intrinsic Motivation Inventory in a competitive sport setting: A confirmatory factor analysis. Research Quarterly for Exercise and Sport, 60(1), 48-58. doi: 10.1080/02701367.1989.10607413

Muthen, L. \& Muthen, B. (1998 - 2017). Mplus user’s guide. Eight Edition. Los Angeles, CA: Muthen \& Muthen.

Newton, M. \& Duda, J. L. (1993). The perceived motivational climate in sport questionnaire2: construct and predictive validity. Journal of Sport and Exercise Psychology. 15, 172172. doi: 10.1123/jsep.15.2.172

Nicholls, J. G. (1984). Achievement Motivation: Conceptions of Ability, Subjective Experience, Task Choice, and Performance. Psychological Review, 91(3), 328-346.

Ntoumanis, N. (2001). A self-determination approach to the understanding of motivation in physical education. British Journal of Educational Psychology 71, 225-242.

Ommundsen, Y. (2006). Psykologisk læringsklima i kroppsøving og idrett. I Ingebrigtsen, J. E. \& Sigmundsson, H. (Red.), Idrettspedagogikk (s. 47-61). Oslo: Universitetsforlaget.

Ommundsen, Y. \& Kvalø, S. E. (2007). Autonomy-master Supportive or Performance Focused? Different teachers behaviors and pupils' outcomes in physical education. Scandinavian Journal of Educational Research 51(4), 385-413. doi: 10.1080/00313830701485551 
Pintrich, P. R., Smith, D. A., Garcia, T. \& McKeachie, W. J. (1991). A Manual for the Use of the Motivated Strategies for Learning Questionnaire (MSLQ). Ann Arbor, MI: National Center for Research to Improve Postsecondary Teaching and Learning, University of Michigan.

Ponterotto, J. G. \& Ruckdeschel, D. E. (2007). An Overview of Coefficient Alpha and a Reliability Matrix for Estimating Adequacy of Internal Consistency Coefficients with Psychological Research Measures. Perceptual and Motor Skills, 105, 997-1014. doi: 10.2466/PMS.105.3.

Reeve, J. \& Jang, H. (2006). What Teachers Say and Do to Support Students’ Autonomy During a Learning Activity. Journal of Educational Psychology, 98(1), 209-218. doi: 10.1037/0022-0663.98.1.209

Reinboth, M. \& Duda, J. (2006). Perceived motivational climate, needs satisfaction and indices of well-being in team sports: A longitudinal perspective. Psychology of Sport and Exercise, 7(3), 269-286. doi: 10.1016/j.psychsport.2005.06.002

Roberts, G. C. (2001). Understanding the dynamics of motivation in physical activity: The influence of achievement goals on motivational processes. In G.C. Roberts (Ed.), Advances in motivation in sport and exercise, 1-50. Champaign, IL: Human Kinetics.

Ryan, R. M. \& Deci, E. L. (2000). Intrinsic and Extrinsic Motivations: Classic Definitions and New Directions. Contemporary Educational Psychology, 25, 54-67. doi:10.1006/ceps.1999.1020

Ryan, R. M. \& Deci, E. L. (2007). Active Human Nature: Self-Determination Theory and the Promotion and Maintenance of Sport, Exercise, and Health. In Hagger, M. S. \& Chatzisarantis, N. L. D (Red.), Intrinsic Motivation and Self-Determination in Exercise and Sport (1-19). United States of America: Human Kinetics.

Ryan, R. M. \& Deci, E. L. (2017). Self-Determination Theory: Basic Psychological Needs in Motivation, Development and Wellness. New York: The Guilford Press.

Säfvenbom, R., Haugen, T. \& Bulie, M. (2014). Attitudes toward and motivation for PE: who collects the benefits of the subject? Physical Education and Sport Pedagogy, 20(6), 629646. doi: 10.1080/17408989.2014.892063

Skaalvik, E. M. \& Skaalvik, S. (2015). Motivasjon for læering. Teori + praksis. Oslo: Universitetsforlaget.

Standage, M., Duda, J. L. \& Ntoumanis, N. (2005). A test of self-determination theory in school physical education. British Journal of Educational Psychology, 75(3), 411-433. doi:10.1348/000709904X22359

Standage, M., Duda, J. L. \& Ntoumanis, N. (2006). Students' Motivational Processes and Their Relationship to Teacher Ratings in School Physical Education: A SelfDetermination Theory Approach. Research Quarterly for Exercise and Sport, 77(1), 100110. doi: 10.1080/02701367.2006.10599336

Strandkleiv, O. I. (2006). Motivasjon i praksis. Håndbok for læerere. Oslo: Elevsiden DA.

Sun, H. \& Chen, A. (2010). A Pedagogical Understanding of the Self-Determination Theory in Physical Education. National Association for Kinesiology and Physical Education in Higher Education, 62, 364-384.

Taylor, I. M. \& Lonsdale, C. (2010). Cultural Differences in the Relationships Among Autonomy Support, Psychological Need Satisfaction, Subjective Vitality, and Effort in British and Chinese Physical Education. Human Kinetics Journal, 32(5), 655-673.

Ulstad, S. O., Halvari, H., Sørebø, Ø. \& Deci, E. L. (2016). Motivation, Learning Strategies, and Performance in Physical Education at Secondary School. Advances in Physical Education, 6, 27-41. doi: 10.4236/ape.2016.61004 
Utdanningsdirektoratet. (2012). Endringer i faget kroppsøving. (Udir-8-2012) Hentet fra https://www.udir.no/regelverk-og-tilsyn/finn-regelverk/etter-tema/Innhold-iopplaringen/Udir-8-2012/

Utdanningsdirektoratet. (2015). Læreplan i kroppsøving. Hentet fra https://www.udir.no/kl06/KRO1-03

Vansteenkiste, M. \& Ryan, R. M. (2013). On Psychological Growth and Vulnerability: Basic Psychological Need Satisfaction and Need Frustration as a Unifying Principle. Journal of Psychotherapy Integration, 23(3), 263-280. doi: 10.1037/a0032359

Zhang, T. (2009). Relations among school students' self-determined motivation, perceived enjoyment, effort and physical activity behaviors. Perceptual and Motor Skills, 109(3), 783-790. doi: 10.2466/pms.109.3.

Zhao, Q. \& Li, W. (2016). Measuring Perceptions of Teachers' Caring Behaviors and Their Relationship to Motivational Responses in Physical Education Among Middle School Students. The Physical Educator, 73, 510-529. doi: 10.18666/TPE-2016-V73-I3-65 